\title{
MEDIA LITERASI: UPAYA BIJAK MENYIKAPI TERPAAN TAYANGAN TELEVISI
}

\author{
Wira Respati \\ Marketing Communication Department, Faculty of Economic and Communication, BINUS University \\ Jln. KH. Syahdan No.9, Palmerah, Jakarta Barat 11480 \\ warespati@gmail.com
}

\begin{abstract}
The television media have transformed into industry. Tight competition among TV stations demands the media people to provide programs based on the market taste. Therefore, mostly TV stations design and produce their programs based on share and rating numbers, instead of quality. On the other side, TV stations have important roles in constructing social and cultural development. Currently, TV programs are merely produced based on the business orientation so that the quality of the TV programs is often ignored. Audience must be wise and smart to protect themselves from poor-quality TV programs exposure. This can be achieved by improving their Media Literacy. In the end, Audience is no longer treated as passive object, but actively takes control on the content selection.
\end{abstract}

Keywords: television industry, TV program, media literacy, social and cultural development

\begin{abstract}
ABSTRAK
Media televisi telah berubah menjadi industri. Persaingan yang ketat antar-stasiun TV menuntut orangorang media untuk memberikan program berdasarkan pada selera pasar. Oleh karena itu, sebagian besar stasiun TV merancang dan memproduksi program mereka berdasarkan nomor share dan rating, bukan kualitas. Pada sisi lain, stasiun TV memiliki peran penting dalam pengembangan sosial dan budaya. Saat ini, program TV hanya diproduksi berdasarkan pada orientasi bisnis sehingga kualitas program TV sering diabaikan. Pemirsa harus bijak dan cerdas untuk melindungi diri dari paparan program TV kualitas rendah. Hal ini dapat dicapai dengan meningkatkan daya Sadar Media mereka. Pada akhirnya, Pemirsa tidak lagi diperlakukan sebagai objek pasif, tetapi secara aktif mengambil kendali pada pemilihan konten.
\end{abstract}

Kata kunci: industri televisi, program TV, sadar media, perkembangan sosial dan budaya 


\section{PENDAHULUAN}

Sebagai produk ilmu pengetahuan dan teknologi di bidang komunikasi, televisi memberikan kontribusi besar bagi kehidupan manusia. Hampir seluruh warga di nusantara baik di kota maupun desa, memiliki pesawat televisi. Media yang satu ini sudah menjadi kebutuhan sebagaimana fungsinya sebagai media penyaji informasi, hiburan, bisnis, pendidikan termasuk memengaruhi pola dan gaya hidup manusia. Ini semua karena kelebihan televisi yang mampu menyatukan unsur audio sekaligus visual. Televisi memiliki keuntungan atas pesannya yang bisa dilihat serta didengar dalam waktu yang bersamaan (Suhandang, 2005: 89).

Sebagai penyaji informasi, televisi memberikan kontribusi sosial dengan melaporkan hingga membahas realita sosial lewat program berita, features atau dialog dengan mengundang pelaku dan pakar sebagai narasumbernya. Televisi juga menawaran program hiburan beragam seperti sinetron, komedi, film, kuis dan reality show. Sajian ini sedianya digemari, tinggi dari sisi rating dan menarik bagi pengiklan. Sebagaimana media televisi menjadi industri, pelaku media (pemilik dan pengelola) lazimnya berorientasi profit-taking dengan menjual slot pada program tayangan tertentu pada pemasang iklan, di saat yang sama menjaga loyalitas khalayak (pemirsa) melalui program tayangan sesuai selera mereka. Pada akhirnya tayangan berikut jam siar hingga durasi dapat dilihat sebagai komoditas dengan pemasang iklan sebagai konsumen, dengan khalayak sebagai target pasar.

Untuk itu pelaku industri televisi cenderung memproduksi program acara yang mudah diserap pasar. Semakin banyak pemirsanya, maka ratingnya baik dan menarik pemasang iklan. Akhirnya mutu tayangan kurang diperhatikan. Banyak program yang menghiasi layar kaca umumnya mengangkat tema HVS-GG atau horror, violence, sex, ghost, glamour. Tema-tema seperti ini dinilai mengabaikan rasionalitas penonton (Hamad, 2007: 202).

Terpaan tayangan televisi ibarat koin dengan dua sisi, bermanfaat namun pada saat yang bersamaan memberikan pengaruh negatif dalam kehidupan manusia. Sejumlah media terus melansir reaksi orangtua akan tayangan televisi terhadap proses pertumbuhan anaknya baik dari segi mental maupun fisik. Di samping itu masih banyak buku lainnya yang substansinya mengkritik tayangan televisi. Pengkajian isi media dinilai penting seiring dengan banyaknya pihak yang kuatir dengan terpaan tayangan televisi dewasa ini. Ada indikasi ruang publik lebih banyak diisi dengan tayangan yang terorientasi pada dimensi pasar ketimbang mengedepankan tanggung jawab sosialnya pada dimensi kultural (Pendidikan, Humaniora dan keagamaan). Aspek ini kurang mendapat tempat secara proporsional (Sanityastuti, 2007: 190).

Realita ini semakin kentara dengan bertranformasinya bisnis media televisi Indonesia yang mengarah pada monopoli. Paulus Widianto Inisiator UU penyiaran dalam sebuah artikel Investor Daily pada 7 April 2011 menyatakan, motivasi untuk melanggengkan bisnis di blantika industri televisi Indonesia juga memunculkan dimensi baru, yakni dimensi politik. Di sini kebijakan pemilik modal, direksi termasuk penyelenggara media televisi turut memengaruhi sajian tayangan televisi. Dominasi dimensi politik dan ekonomi ini baik secara langsung maupun tidak langsung menggerus nilai-nilai kultural dalam masyarakat seperti ruang kebebasan dan netralitas, rasionalitas, kecerdasan dan kemanusiaan. Padahal peran dasar media sendiri sangat diandalkan sebagai pengembangan wacana publik untuk konstruksi sosial.

Berangkat dari kenyataan tersebut maka pertanyaan-pertanyaan inti yang ingin di jawab oleh penulis adalah, apakah televisi Indonesia sudah cukup melakukan tanggung jawab sosialnya sebagai pegusung nilai-nilai cultural selain mengedepankan nilai-nilai politik dan ekonominya? Dan langkahlangkah bijak apa yang sebenarnya dapat dilakukan masyarakat ketika peran tersebut tidak berjalan sepenuhnya. Diharapkan melalui tulisan ini masyarakat Indonesia sebagai khalayak dapat membangun 
pola pikir kritis, tidak senantiasa menjadi objek yang pasif dalam menerima terpaan tayangan televisi. Sedianya khalayak di Indonesia tetap menerima manfaat positif tayangan televisi untuk meningkatkan kualitas hidup namun disisi lain sedapat mungkin dapat mereduksi dampak negatif terpaan tayangan televisi, utamanya pengaruh dalam pembentukan mental generasi yang akan datang.

\section{METODE PENELITIAN}

Untuk mengetahui media literasi diperlukan bagi khalayak di Indonesia saat terpapar tayangan televisi, maka penting untuk mengetahui dinamika industri televisi di negeri ini. Maka dari itu, penulis menggunakan metode kualitatif untuk menggali lebih dalam apa saja yang melatarbelakangi para praktisi industri televisi memformulasikan program acara sebelum ditayangkan. Riset kualitatif sendiri bertujuan untuk menjelaskan fenomena sedalam-dalamnya. Di sini, yang lebih ditekankan adalah persoalan kedalaman (kualitas) data bukan banyaknya (kuantitas) data (Kriyantono, 2012: 57). Format desain penelitian ini adalah deskriptif. Peneliti bertujuan untuk menggambarkan, meringkaskan berbagai kondisi, berbagai situasi atau berbagai fenomena realitas sosial yang ada di masyarakat yang menjadi objek penelitian. Selain melakukan studi literatur pada penelitian sebelumnya, peneliti menggunakan pendekatan studi kasus pada beberapa program acara yang masuk dalam daftar pengaduan khalayak pada komisi penyiaran Indonesia. Ini penting untuk mengetahui karakteristik program yang dinilai khalayak berdampak negatif jika mereka terus terpapar tayangan program tersebut.

Dalam penelitian, penulis akan membuktikan apakah asumsi teori Uses and Gratification dan konsep media literasi relevan dalam menjawab fenomena. Kecenderungan yang terjadi saat ini adalah, praktisi stasiun televisi menformulasikan program acaranya berdasarkan minat tonton pemirsa yang terefleksikan melalui rating dan share. Penulis akan menjelaskan bagaimana penggunaan teori Uses and Gratification Herbert Gulmer dan Elihu Katz dalam memahami bagaimana khalayak menggunakan media sebagai pemuas kebutuhannya. Karena itulah pengguna media atau khalayak, memainkan peran aktif untuk memilih dan menggunakan media (McQuail, 1987: 236). Peran khalayak termasuk perilaku dan motivasi mereka dalam memilih dan menggunakan media menjadi asumsi awal bertransformasinya media televisi menjadi sebuah industri penyiaran yang komersial. Selanjutnya penulis akan mengkaitkannya dengan konsep media literasi yang merupakan hasil kajian kritis Fernand dan Braudel. Seperti yang ditulis dalam Media Now: Understanding Media, Culture and Technology, Media Literasi merupakan kajian kritis terhadap peran media dalam masyarakat bahwa seharusnya khalayak tidak diberlakukan sebagai konsumen yang pasif (Straubhaar\&LaRose, 2006: 41). Media memiliki tanggung jawab sosial yang belakanan cenderung terlupakan akibat motif praktisi industri televisi untuk terus-menerus mendongkrak rating.

Teknik pengumpulan data dilakukan melalui studi kepustakaan dilengkapi wawancara praktisi televisi berikut laporan rating televisi mingguan yang akan menjadi indicator jika program dimaksud cukup diminati oleh khalayak, sehingga hal tersebut menjadi dasar praktisi televisi untuk menyusun program acara selanjutnya. Sebagai teknik validasi data, peneliti menggunakan trianggulasi sumber atau data, trianggulasi metode, dan trianggulasi peneliti. Trianggulasi sumber atau data menunjukkan upaya peneliti untuk memperoleh data berkenaan dengan persoalan yang sama. Trianggulasi Data diperoleh dari para key informan yang terkait langsung dalam penyusunan program acara di stasiun SCTV. Trianggulasi metode dilakukan dengan membandingkan temuan data yang diperoleh dengan analisis dokumen relevan. Trianggulasi peneliti juga dilakukan dengan melibatkan pemikiran dari dua peneliti yang sebelumnya pernah melakukan penelitian tentang media literasi. 


\section{HASIL DAN PEMBAHASAN}

\section{Transformasi Media Televisi Indonesia Menjelma Menjadi Industri}

Menelisik sejarah perkembangan industri televisi di Indonesia, tentu harus bermula dari kelahiran Televisi Republik Indonesia sebagai stasiun televisi pertama di Indonesia. TVRI mengudara sejak tahun 1962 di Jakarta. Didirikannya TVRI berangkat dari kebutuhan menyebarluaskan informasi perhelatan Asian Games IV yang diselenggarakan di Jakarta kala itu. Persiapannya dilakukan dibawah koordinasi urusan proyek Asian Games IV. Kelahiran TVRI yang bukan didasari kebutuhan masyarakat membuat pengelolaannya terkesan prematur terlebih dengan keterbatasan sumber daya manusia kala itu. Situasi ini menjadi semakin ironis ketika TVRI pada era orde baru lebih berperan menjadi pengawal kekuasaan. Tahun 1974, TVRI diubah menjadi salah satu bagian dari organisasi dan tata kerja Departemen Penerangan, yang diberi status direktorat. Sebagai alat komunikasi Pemerintah, tugas TVRI menyampaikan informasi tentang kebijakan Pemerintah kepada rakyat. Program-program tayangannya sebagian besar menunjukkan hegemoni penguasa dan memposisikan masyarakat sebagai objek yang pasif. Dalam konteks kultural TVRI tidak cukup berperan dalam membangun kontruksi sosial yang nyata sementara dalam konteks ekonomi tidak ada iklim kompetisi yang menarik bagi pemasang iklan (Wirodono, 2006:6). Baru pada awal dekade 1990-an, kemunculan televisi swasta menuntut TVRI harus berbenah, karena tidak lagi menjadi satu-satunya penguasa industri televisi di tanah air. Akhir dari pemerintahan presiden yang menandai akhir dari era orde baru pada tahun 1998 sontak mengakhiri dominasi TVRI sebagi corong pemerintah. Saat ini status TVRI saat ini adalah Lembaga Penyiaran Publik. Biaya operasional TVRI tak lagi sepenuhnya ditanggung oleh negara.

Saat ini keberadaan TVRI sebagai Lembaga Penyiaran Publik diharapkan mampu menjadi media pencerdasan bangsa sementara televisi swasta berpijak pada aspek komersialnya. TVRI menjadi andalan memberikan layanan informasi untuk kepentingan publik, bersifat netral dan mandiri sebagaimana yang tertuang dalam Peraturan Pemerintah Nomor 13 tahun 2005 menetapkan bahwa tugas TVRI adalah memberikan pelayanan informasi, pendidikan dan hiburan yang sehat, kontrol dan perekat sosial, serta melestarikan budaya bangsa untuk kepentingan seluruh lapisan masyarakat melalui penyelenggaraan penyiaran televisi yang menjangkau seluruh wilayah Negara Kesatuan Republik Indonesia. Masalahnya, sejauh mana program tayangan TVRI mampu bersaing secara professional ditengah eksistensi televisi swasta yang ditopang pendanaan dari iklan dan mengedepankan rating sebagai tolok ukur taste atau selera pemirsa. Kondisi ini membuat misi TVRI mengembangkan dimensi kultural masyarakat Indonesia mendapat tantangan berat.

Kehadiran televisi-televisi swasta pun tidak serta merta menjadi jaminan terselenggaranya televisi yang bertanggung jawab dalam mengembangkan aspek kultural itu. Bisnis televisi swasta awalnya pun berkutat di lingkaran keluarga Soeharto. Rajawali Citra Televisi Indonesia (RCTI) yang memulai siarannya tahun 1989 didirikan oleh putranya Bambang Trihatmodjo putra Soeharto, Surya Citra Televisi (SCTV) tahun 1990 oleh Sudwikatmono yang masih berada dalam lingkaran keluarga Cendana, menyusul setahun kemudian mengudaranya Televisi Pendidikan Indonesia (TPI) oleh Siti Hardianti Rukmana yang tak lain adalah putri tertua Soeharto. Selain itu keberadaan ANTV yang didirikan Abu Rizal Bakrie tahun 1993 dan Indosiar oleh Salim Group pada tahun 1995 juga sarat dengan nuansa KKN (Korupsi, Kolusi dan Nepotisme) mengingat keleluasaan bisnis industri televisi masih di dominasi kelompok-kelompok tertentu (Wirodono, 2006:8). Belakangan wajah industri televisi Indonesia masih belum menunjukkan format industri yang seharusnya. Ketika muncul desakan industri televisi Indonesia harus mewadahi keberagaman kultural di tanah air melalui penyelenggaraan stasiun televisi lokal, sejumlah pelaku industri televisi malah menjelma menjadi gurita yang memonopoli tayangan televisi. Hal ini jelas melanggar prinsip-prinsip Undang-undang (UU) Nomor 32 Tahun 2002 tentang penyiaran, yaitu kepemilikan harus beragam demikian juga dengan isi siaran. 
Saat ini MNC menjadi grup usaha yang menguasai tiga stasiun TV nasional dan 10 televisi lokal. Padahal dalam UU Penyiaran tertera bahwa satu grup media tidak boleh memiliki dua atau lebih stasiun televisi swasta di dalam satu area yang sama. Meskipun dalih yang digunakan adalah pengambilan saham namun subtansinya sama dengan penguasaan frekuensi dan informasi. Sedianya setiap warga negara berhak mengelola frekuensi dan informasi bukan hanya sekelompok orang. Contoh lain yang dinilai menyalahi ketentuan undang-undang adalah induk perusahaan SCTV (PT. Elang Mahkota Teknologi Tbk) yang pada tahun 2012 ini resmi mengakuisisi Indosiar. Langkah serupa juga di tempuh Grup media seperti Viva Group yang menaungi ANTV dan TVOne dan Trans Corp dengan Trans TV dan Trans 7. Tak sedikit diantara grup media ini bahkan kemudian mengambil alih izin penyiaran TV lokal di berbagai daerah. Padahal keberadaan televisi lokal di tujukan untuk mengemban misi demokratisasi, pluralisme serta kearifan lokal di seluruh nusantara. kalau sudah begini tak cuma monopoli tapi juga konglomerasi industri televisi yang sudah menjadi tradisi sejak zaman pemerintahan Soekarno hingga pemerintahan Susilo Bambang Yudhoyono. Ketatnya persaingan televisi dan tingginya biaya operasional menjadi dalih bagi mereka ketika dituding belum melaksanakan tanggung jawab sosial mereka sepenuhnya.

Terlepas dari polemik status kepemilikan, ketidaktegasan penegakan UU penyiaran juga jadi sorotan. Televisi swasta saat ini RCTI, SCTV, MNC, ANTV, Indosiar, Metro TV, TV One, Trans TV, Trans 7 dan Global TV kini bersaing ketat mencari pendanaan sebanyak-banyaknya namun disaat yang sama memproduksi tayangan seefisien mungkin agar dapat bertahan di tengah ketatnya persaingan industri televisi saat ini. Program-program televisi berkiblat pada rating karena lebih membela kepentingan pemasang iklan alih-alih kebutuhan masyarakat akan informasi yang berkualitas. Ketimbang merefleksikan realitas kultural yang sesungguhnya, televisi justru menyajikan realitas sekunder dan produk kebudayaan yang mengubah kebudayaan itu sendiri sehingga tak lagi memiliki karakter yang jelas (Wirodono, 2006: 25) Program televisi tak lagi beragam karena semuanya kembali berpulang pada angka rating dan share.

\section{Menelisik Isi Tayangan Televisi Indonesia}

Melalui tayangannya televisi memiliki kemampuan untuk mengkonstruksikan suatu peristiwa, bahkan mampu untuk membentuk suatu realita sosial. Dengan kata lain program-program acara televisi dengan sendirinya akan memberi pengaruh dan dampak kepada khalayak. Program acara televisi yang lazim di jumpai diberbagai stasiun televisi dewasa ini adalah:

\section{Berita}

Perkembangan pemberitaan televisi di Indonesia terbilang unik. Di zaman orde baru, program berita produksi TVRI masih mendapat tempat utama, bahkan stasiun televisi swasta yang sudah ada wajib me-relay berita TVRI sekalipun RCTI dan SCTV sudah memproduksi program berita sendiri seperti Seputar Indonesia (RCTI) dan Liputan 6 (SCTV). Awalnya konten program berita lebih disampaikan secara ringan seperti features dan dokumenter. Namun seiring dengan desakan kebebasan berekspresi, semangat reformasi yang puncaknya adalah keruntuhan orde baru, semua stasiun televisi swasta merancang program beritanya sendiri. Berpijak pada undang undang kebebasan pers No.40 tahun 1999, kini seluruh stasiun televisi di Indonesia berlomba-lomba menyajikan informasi faktual yang sorotan masyarakat luas. Kru liputan dikerahkan hingga pelosok nusantara bahkan peristiwaperistiwa besarpun disiarkan langsung dari lokasi kejadian. Namun begitu label idustri yang melekat pada media televisi pada akhirnya ikut memengaruhi kebijakan news room atau redaksi. Efisiensi pada biaya operasional dan sumber daya manusia pada akhirnya memengaruhi isi tayangan berita televisi. Dari sisi kemasan, keharusan meraih rating dan share yang bagus kadang mengurangi kualitas sebuah tayangan berita. Selain alasan ekonomi, kepemilikan media oleh kelompok elit atau penguasa turut memberikan pengaruh baik secara langsung ataupun tidak langsung. Sebut saja pemilik Viva Media Group yaitu Abu Rizal Bakrie yang tak lain adalah politisi partai Golkar. Atau Surya Paloh dan Hari 
Tanoesoedibjo dari Media Group yang sekaligus politisi Nasional Demokrat. Mereka kini berkiprah dalam pentas politik sehingga membuka peluang pemanfaatan media sebagai corong kepentingan politik mereka. Artikel "Karni Ilyas: Ical Intervensi berita” yang dimuat dalam liputan6.com pada tanggal 6 maret 2012, menunjukkan adanya indikasi bentuk intervensi pemilik modal yang kemudian dicoba dibantah oleh pemimpin redaksinya. Jika dibedah lebih jauh ada rivalitas kepentingan antara pemilik saham sekaligus kubu politik Golkar dengan kubu politik penguasa Demokrat. Demokrat menuding, TV One diintervensi ownernya untuk mengekspos kasus yang menjerat kader politisi partai demokrat dalam kubangan kasus suap Wisma Atlet SEA Games. Pada kasus lainnya, sudah bukan rahasia umum lagi minimnya porsi pemberitaan bencana lumpur lapindo di ANTV dan TV One juga dikait-kaitkan dengan kepentingan bisnis keluarga Bakrie. Lebih lanjut Wirodono dalam artikel “Televisi Ruang Publik yang di Rampok” tanggal 15 desember 2011 di www.remotovi.or.id mengatakan, penguasaan yang absolut atas media, oleh para pemiliknya, pada akhirnya adalah pelemahan publik itu sendiri, karena di Amerika pun, juga Perancis, Jepang, dan negara-negara maju lainnya, tidak pernah membiarkan absolutisme media. Hanya di Indonesia kita bisa melihat kenyataan bagaimana Surya Paloh mengawinkan kuasa media dengan politik, sebagaimana Kompas TV bermain di antara berbagai kelemahan itu.

Di bidang penegakan hukum, tayangan berita televisi kadang sering membangun opini publik bahkan sebelum vonis oleh pengadilan menjatuhkan vonis. Seperti yang dilansir dalam artikel "Zulkarnaen dan Anaknya Merasa Dihukum sebelum Vonis Jatuh”, dimana Zulkarnaen anggota komisi VIII DPR ini menjadi tersangka kasus korupsi pengadaan Alquran, di Departemen Agama namun ekspos media memberikan kesan ia sudah menjadi terpidana meski putusan pengadilan belum dikeluarkan (www.tribunnews.com, 9 juli 2012). Tidak kalah mengkuatirkan cara pengemasan berita yang kerap tidak mengikuti kaidah jurnalistik. Untuk menarik khalayak, stasiun televisi mencoba menggugah emosi khalayak dengan jurus-jurus eksploitasi kesedihan korban bencana atau tindak kriminalitas. Termasuk ekspos tindak kekerasan bahkan asusila baik secara narasi maupu visualisasi. Hal-hal tersebut justru menyesatkan khalayak dari substansi berita itu sebenarnya. Contoh bentuk pelanggaran yang mendapat sorotan lembaga pengawas penyiaran independen Indonesia atau KPI adalah sebagai berikut.

Tabel 1 contoh bentuk pelanggaran yang dilakukan televisi

\begin{tabular}{ll}
\hline Tgl Surat & 8 Agustus 2012 \\
No. Surat & $490 / \mathrm{K} / \mathrm{KPI} / 08 / 12$ \\
Status & Teguran Tertulis \\
Stasiun TV & SCTV \\
Program & Siaran "Liputan 6 Pagi" \\
Deskripsi Pelanggaran & Pada tanggal 4 Juli 2012 pukul 05.19 WIB menayangkan \\
& gambar sepasang pria dan wanita yang mengesankan \\
& berciuman bibir. Jenis pelanggaran ini dikategorikan sebagai \\
& pelanggaran atas pelarangan adegan seksual, perlindungan \\
& anak dan remaja, serta norma kesopanan dan \\
& kesusilaan.Tindakan menayangkan adegan tersebut telah \\
& melanggar P3 tahun 2012 Pasal 9, Pasal 14 ayat (2), dan \\
& pasal 16 serta SPS Pasal 9, Pasal 15 ayat (1), dan Pasal 18 \\
& huruf k. \\
\hline
\end{tabular}




\begin{tabular}{ll}
\hline Tgl Surat & 6 Juni 2011 \\
No. Surat & $415 / \mathrm{K} / \mathrm{KPI} / 06 / 11$ \\
Status & Teguran Tertulis Kedua \\
Stasiun TV & Metro TV \\
Program & Metro Siang \\
Deskripsi Pelanggaran & Pada tanggal 14 April 2011 pukul 11.34 WIB menayangkan \\
& wajah dan identitas anak sebagai pelaku tindak pidana \\
& perjudian. Tindakan penayangan tersebut telah melanggar P3 \\
& Pasal 10, Pasal 18 ayat (2), SPS Pasal 13 ayat (1) dan Pasal 42 \\
& ayat (1) huruf a serta KEJ Pasal 5. \\
\hline
\end{tabular}

Sumber: Komisi Penyiaran Indonesia, 29 Agustus 2012

\section{Sinetron}

Sinetron atau sinema elektronik pada dasarnya sama dengan sinema layar lebar. Yang membedakan adalah teknik penyajian dan karakteristik media yang menayangkannya. Jika khalayak dapat menyaksikan sinema layar lebar secara utuh tanpa terganggu iklan maka sebaliknya sinetron harus di sajikan dengan mempertimbangkan tayangan iklan dan menjaga kesinambungan cerita guna menjaga minat tonton khalayak. Karenanya dalam menggarap sinetron, aspek penulisan skenario, casting, penyutradaraan hingga durasi penayangan memerlukan perhatian khusus. Untuk menutupi kebutuhan tayangan sebuah stasiun televisi, sinetron bisa diproduksi dalam jumlah puluhan bahkan ratusan episode sehingga pengerjaannya kerap kejar tayang. Apalagi saat ini sinetron merupakan program acara yang diminati, indikasinya tak lain adalah rating dan share. Diagram dan tabel berikut menggambarkan perolehan share televisi pada minggu keempat Agustus 2012, dan top program SCTV sebagai peraih share terbesar di waktu yang sama.

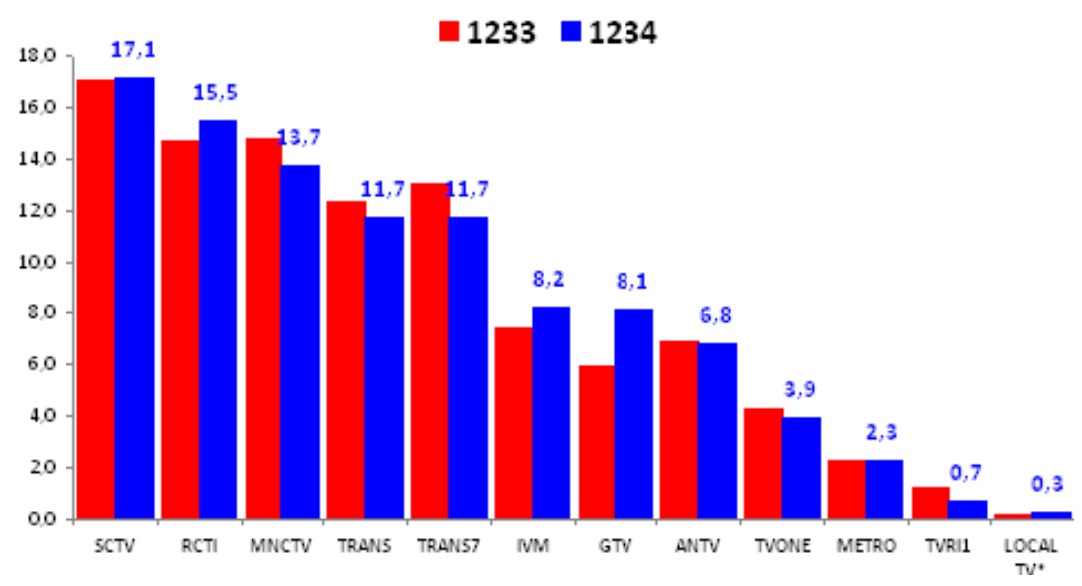

Gambar 1 Top 10 Program SCTV - 28 August 2012 Based on All Time, 10 Cities, ABC 5 
Tabel 2 Top 10 program SCTV

\begin{tabular}{cllcc}
\hline No & \multicolumn{1}{c}{ Program Name } & \multicolumn{1}{c}{ Type } & TVR & Share \\
\hline 1 & PUTIH ABU - ABU & Series:Drama & 3,0 & 11,9 \\
2 & 6K CAKE CINTA FLARA & Movie:Drama & 2,4 & 22,6 \\
3 & 6I DON'T WORRY BE HAPPY,JUL & Movie:Drama & 2,3 & 18,1 \\
4 & 6J MUTIARA CINTA DARI BROMO & Movie:Drama & 2,2 & 13,8 \\
5 & LIPUTAN 6 SIANG & News:Hard News & 2,2 & 18,3 \\
6 & HALO SELEBRITI & Information:Infotainment & 2,0 & 20,0 \\
7 & SI BIANG KEROK & Series:Drama & 1,8 & 7,6 \\
8 & ABU NAWAS DAN PAMAN JIN & Series:Drama & 1,8 & 10,1 \\
9 & JEBAKAN BETMEN NEW & Entertainment:Reality Show & 1,8 & 20,4 \\
10 & EAT BULAGA! INDONESIA & Entertainment:Variety Show & 1,8 & 17,4 \\
\hline
\end{tabular}

Sumber: Nielsen, Agustus 2012

Dari diagram serta tabel di atas dapat dilihat program acara yang memilik rating dan share terbesar pada stasiun televisi SCTV masih didominasi sinetron drama dan sinetron lepas, membawahi program acara lainnya seperti berita dan infotainment. SCTV sendiri pada minggu keempat Agustus 2012, memimpin dalam perolehan share pemirsa pada target ABC 5+ atau khalayak pemirsa kelas bawah dan menengah di 5 kota besar, kelas yang merupakan segmen terbesar khalayak televisi di Indonesia. Industri televisi biasanya mempercayakan proses pembuatan sinetron kepada production house guna mengurangi beban operasional dan biaya. Kebutuhan kuantitas tayangan sinetron pada akhirnya mengabaikan aspek kualitas sinetron itu sendiri. Dari sisi konten, sistem kejar tayang pada akhirnya mendorong production house memilih cara aman dalam mengemas sinetron, tujuannya agar sinetron yang mereka garap dapat diterima khalayak dan pada akhirnya mendongkrak rating dan share. Tema-tema percintaan, intrik rumah tangga dan drama remaja biasanya kerap menjadi pilihan, sehingga wajar saja bila isi tayangan sinetron terkesan monoton dan miskin cerita, tidak mendidik, tidak kreatif, mudah ditebak dan berulang-ulang. Kadang bila sinetron tersebut meraih rating tinggi, pelaku industri tidak segan-segan membuat episode lanjutan meski dengan jalan cerita yang dipaksakan. Inilah yang membuat cerita yang diangkat sinetron, jauh dari realitas sosial. Meskipun begitu, tak dapat dipungkiri tayangan sinetron masih mendapat porsi besar, walaupun tema yang diangkat suatu stasiun televisi dengan stasiun televisi lainnya terkesan itu-itu saja.

\section{Infotainment}

Sukses PT. Bintang Advis mengemas informasi selebriti dunia hiburan dalam program Cek \& Ricek berdurasi 30 menit, dengan mudah diikuti program-program serupa di berbagai stasiun televisi lainnya. Pasalnya tidak seperti program berita aktual yang membutuhkan biaya operasional besar, infotainment penggarapannya relatif mudah dan berbiaya murah, kebanyakan stasiun televisi swasta lebih suka membeli produksi production house. Sampai saat ini penayangan infotainment mencapai angka lebih dari 200 episode dalam seminggu atau 15 jam dalam sehari (Sunityastuti, 2007:195). Kendati Infotainment di produksi dengan biaya murah namun program yang satu ini memiliki nilai jual tinggi karena cukup digemari khalayak. Program ini menyajikan sisi pribadi tokoh yang menjadi sorotan masyarakat, selebriti atau orang populer. Penggarapannya mudah karena tidak mengedepankan kualitas tayangan seperti halnya pada program berita aktual. Penggarapan kerap dibuat sambil lalu semenara khalayak akan digiring pada pencitraan yang melekat kuat pada subjek yang diliput. Penyajiannya pun dibuat sedimikian rupa, melalui narasi dan penampilan presenter, khalayak seolah-olah diajak langsung merasakan kehidupan tokoh selebritas yang lazimnya diidamidamkan banyak orang. Infotainment pun menawarkan simbiosis mutualisme bagi tokoh yang diliput, karena menjadi media pencitraan guna mendongkrak popularitasnya di mata masyarakat. 


\section{Reality Show}

Reality Show adalah tayangan televisi yang berangkat dari upaya mengangkat realitas-realitas yang terjadi di masyarakat. Namun reality show yang sering disajikan televisi swasta Indonesia sampai saat ini cenderung lebih banyak mengagkat tema-tema kemiskinan. Eksploitasi air mata dan penderitaan jadi andalan untuk menggugah emosi khalayak. Sebut saja program reality show seperti Uang Kaget, Rejeki Nomplok, Tolong Dong, Nikah Gratis, Bedah Rumah dan masih banyak lagi. Alih-alih membuka mata khalayak terhadap fakta sosial yang terjadi, kemasan reality show justru terkesan memperlakukan orang miskin dalam program tersebut sebagai objek yang pasif dengan memberikan bantuan yang sifatnya instan dan tidak bentul betul memperbaiki nasib mereka dalam jangka panjang. Ironisnya keuntungan yang dihasilkan dari penayangan program tersebut cukup besar bagi industri televisi swasta. Dikuatirkan khalayak yang menyaksikan program tesebut malah kemudian terbuai dengan harapan mendapat keberuntungan seperti yang disajikan dalam reality show kebanyakan di Indonesia. Penghuni terakhir atau reality show yang bertema perjodohan pun juga minus nilai edukasi. Program ini malah cenderung menayangkan realitas semu karena intrik dan polemik yang teradi terkesan dibuat-buat atau drama yang tidak pernah sungguh-sungguh terjadi dalam dunia nyata.

\section{Komedi}

Panggung komedi masih menjadi tema fovorit program acara televisi sampai saat ini, bahkan acara yang tidak berbasi panggung komedi seperti talk show hingga ceramah agama sekalipun dikemas dengan memasukkan unsur atau nuansa komedi, sehingga menjadikan tayangan tersebut ringan dan segar untuk ditonton khalayak. Namun komedi yang dikemas di Indonesia lazimnya masih mengedepankan lawakan dangkal atau improvisasi ekspresi pelakunya, ibarat lawakan panggung yang dibawa ke layar televisi. Bukan lawakan konseptual namun lebih banyak mengedepankan sensualitas sehingga khalayak mudah mencapai titik jenuh. Tayangan Komedi pada program acara sahur di bulan ramadhan, paling banyak mendapat sorotan hangat. Dari tahun ke tahun, program seperti ini meraih rating tinggi namun ironisnya mengundang kontroversi. Padahal sejatinya Siaran Ramadhan dibuat berdasar bingkai kaidah-kaidah agama serta menggambarkan realita kehidupan masyarakat beragama sehingga siaran ramadhan dapat menumbuhkan dan meningkatkan ketaatan beribadah masyarakat sebagai konsumen televisi.

Dalam sebuah artikel di situs resmi Komisi Penyiaran Indonesia berjudul Tayangan Komedi Ramadhan Tuai banyak sanksi Teguran pada tanggal 8 agustus 2012, Komisioner KPI Pusat Bidang Isi Siaran, Nina Mutmainnah menyatakan, secara umum sejumlah stasiun TV menampilkan acara yang sesuai dengan semangat Ramadhan, lewat acara ceramah, talkshow, features, sinetron dan film serial. Pelanggaran isi siaran justru terdapat pada acara-acara komedi, baik pada saat sahur ataupun menjelang berbuka puasa. Acara yang diindikasikan melanggar kaidah penyiaran pada bulan rmadhan tahun ini adalah: "Waktunya Kita Sahur" (Trans TV), "Kampung Sahur Bejo (RCTI), "Sahur Bersama Srimulat” (Indosiar), “Ngabuburit” (Trans TV), "Sabarrr Tingkat 2” (SCTV), “John Lenong” (Trans 7). Bentuk pelanggaran yang dominan adalah penayangan adegan yang melecehkan orang dengan kondisi fisik tertentu atau dengan orientasi seks dan identitas gender tertentu serta pelanggaran atas norma kesopanan dan norma kesusilaan (KPI, 8 agustus 2012).

\section{Mistik}

Eksploitasi tak cuma di panggung lawak, tapi juga pada khalayak yang masih meyakini halhal di luar logika seperti mistik, dan penghuni alam gaib seperti hantu yang diyakini menganggu kehidupan manusia. Tayangan seperti ini menjadi menarik bagi khalayak karena menjadikan seolaholah hal-hal yang bertentangan dengan rasional manusia menjadi sesuatu yang aktual. Padahal secara logika tidak ada satu pun mahluk gaib yang bisa divisualisasikan oleh kamera hingga dapat disaksikan kasat mata. Namun entah kenapa, pengemasan yang sedemikian rupa guna menghadirkan efek mencekam tampaknya efektif menggiring khalayak untuk percaya. Dapat dibuktikan dengan masih 
ada penayangan program-program serupa oleh stasiun televisi bahkan hingga saat ini. Secara umum kategori-kategori program televisi yang dipaparkan mencerminkan konten tayangan televisi Indonesia dewasa ini. Eksploitasi masih dilakukan untuk meraih keuntungan sebesar-besarnya dari para pemasang iklan. Analisis perkembangan masyarakat Thomas Khun, dapat menjelaskan betapa materi tayangan televisi Indonesia masih dalam tahap anomali (Sanityastuti, 2007:195), bahwa program televisi Indonesia masih jauh dari tanggung jawab sosialnya mengembangkan dimensi kultural masyarakatnya. Lebih sederhananya, tayangan televisi Indonesia masih belum mendidik bahkan memunculkan dampak negatif kepada khalayaknya. Langkah bijak dari otoritas terkait termasuk partisipasi aktif masyarakat dinilai perlu agar tayangan televisi Indonesia dapat memiliki paradigma siaran yang jelas dan lebih mengedepankan nilai manfaat.

\section{Media Literasi: Kritis Memahami Dinamika Industri Televisi}

Melihat peradaban manusia, utamanya realitas sosial dalam kehidupan era informasi saat ini, manusia perlu bijak dalam memahami fenomena-fenomena sosial yang terjadi disekitarnya. Terutama perkembangan media televisi sebagai industri dengan kepentingan kapitalisme global yang mengiringinya. Dalam mengkaji tayangan televisi perlu di pahami bahwa perkembangan industri televisi berpijak pada motivasi bisnis, karena sebagai industri profit taking menjadi sesuatu yang tak dapat dihindari apabila stasiun televisi itu ingin bertahan ditengah kian maraknya persaingan. Artinya ada penawaran antara kebutuhan meraup keuntungan dengan kewajiban sosial televisi sebagai media yang ikut berperan dalam kontruksi sosial masyarakat. Dalam konteks ekonomi pula, kiprah industri televisi berpijak pada aspek "supply dan demand", yang program tayangannya mengikuti kebutuhan pasar. Survei khalayak yang tertuang dalam angka-angka rating dan share kemudian menjadi tolok ukur pelaku industri televisi dalam merancang program acara. Dalam konteks ini sebenarnya khalayak memberikan partisipasi aktif. Sebagaimana yang tertuang dalam teori Uses and Gratification yang dicetuskan Herbert Gulmer dan Elihu Katz. Dalam teori itu, khalayak menggunakan media sebagai pemuas kebutuhannya. Untuk itu pengguna media atau khalayaklah yang sebeneranya memainkan peran aktif untuk memilih dan menggunakan media tersebut (McQuail, 1987: 236). Dengan demikian kita dapat melihat sebenarnya kendali pemilihan program yang akan ditonton pada akhirnya bermuara pada keputusan khalayak. Bila mayoritas khalayak sepakat program yang menurut mereka ideal untuk ditonton, otomatis pelaku industri media akan mengikuti taste mereka, karena khalayak adalah pasar sebenarnya.

Namun dalam mengkaji terpaan tayangan televisi, yang sering dijumpai justru khalayak cenderung terposisikan sebagai objek yang pasif. Mereka rentan akan dampak tayangan televisi, sementara mereka yang memiliki level pendidikan tinggi akan lebih mudah memagari diri dengan beralih ke media alternatif lain misalnya. Seperti yang di tegaskan Wolton, bahwa masyarakat bisa saja terpengaruh oleh program yang buruk, namun membicarakan alienasi baik dan buruk ini bisa dibilang menganggap kemampuan pribadi masyarakat dalam menilai telah hilang (Wolton, 2007:94). Secara langsung maupun tidak langsung status sosial ekonomi dan level pendidikan berpengaruh dalam menentukan preferesi menonon khalayak. Dari tayangan program yang mendominasi layar televisi Indonesia, dapat kita lihat siapa sesungguhnya yang menjadi pemirsa loyal, yaitu mereka yang menyukai tayangan sinetron, infotainment maupun komedi alih-alih program berita atau edukatif lainnya yang sebenarnya lebih mendukung aspek kultural dan kontruksi sosial. Karenanya dapat di maklumi, betapa siaran televisi mengikuti mainstream, tidak beragam dan tidak sepenuhnya mengedepankan mutu dan perannya sebagai media massa yang memberikan pencerahan kepada masyarakat.

TVRI sebagai lembaga publik sedianya memberikan porsi besar dalam menayangkan Program acara berkualitas dan mendidik. Televisi publik juga membangun hubungan yang konstant antara khalayak dengan masalah sentral yaitu identitas nasional. TVRI dalam hal ini berperan membangun komunikasi nasional dan perekat dalam kehidupan bangsa dan Negara. Namun faktanya apa yang 
disajikan televisi publik tidak mendapat sorotan sebesar sajian tayangan program televisi swasta yang bersifat mainstream. Situasi ini tidak boleh dibiarkan begitu saja. Televisi sebagai media komunikasi massa punya kewajiban moral untuk memperluas ragam penawaran kultural dan meningkatkan kematangan politik dan budaya masyarakatnya. Tayangan tidak boleh berpijak pada motivasi bisnis industri yang mengedepankan kuantitas, tapi juga mutu tayangan atau kualitas. khalayak memegang peranan penting, agar mau berpikir kritis dengan tidak melulu menjadi objek terpaan tayangan televisi. Sementara pemerintah yang memiliki otoritas harus mampu memberikan pengawasan ketat terhadap mutu tayangan televisi.

Sonia Livingstone mendefinisikan Media literasi sebagai kemampuan khalayak untuk mengakses, menganalisis, mengevaluasi dan mengkomunikasikan pesan dalam berbagai bentuk medium (Livingstone, 2009). Dengan kemampuan itu khalayak televisi seharusnya menjadi sadar bagaimana media di konstruksi dan diakses. Kemampuan yang kemudian dibahasakan sebagai media literasi ini seharusnya membuat khalayak Indonesia tak lagi dipandang secara pasif. Mereka diharapkan mampu memahami televisi secara utuh baik dalam konteks peranannya dalam meningkatkan kualitas hidup manusia pada dimensi kultural namun disisi lain karakteristiknya sebagai industri. khalayak juga diharapkan dapat menciptakan filter bagi dirinya sendiri untuk memaksimalkan porsi manfaat dan meminimalisasi dampak negatif. Idealnya selain memberikan informasi, wawasan, pengetahuan dan perkembangan budaya, televisi berperan memperlancar hubungan dan komunikasi antar manusia dalam masyarakat, memiliki kecepatan dan keakuratan dalam menyajikan berita, melebihi media massa lainnya seperti surat kabar dan radio. Penulis ingin mempertegas peran media televisi yang harus mendapat porsi besar, yaitu:

\section{Televisi Media untuk Menghibur}

Sebagai hiburan, program-program seperti musik, film, infotainment dan lain-lain dapat mencairkan kejenuhan setelah sehari bekerja keras. Hal itu membuat pikiran kita kembali segar dan melupakan sejenak kelelahan sepanjang hari. Namun, kontennya tidak boleh menjauhkan khlayak dari realitas sosial.

\section{Televisi Memberi Informasi, Pengetahuan dan Pendidikan}

Televisi dapat menyebarkan berita dan gagasan lebih cepat. Berita-berita aktual bisa langsung disebarkan ke berbagai pelosok nusantara secara langsung. Industri pertelevisian di Indonesia harus menayangkan informasi-informasi yang akurat tentang pendidikan dan ilmu pengetahuan untuk menambah wawasan khalayak.

Pengaruh negatif yang harus disadari khalayak di antaranya: terlalu lama menerima terpaan televisi dapat mengurangi produktivitas, menerima terpaan televisi tanpa logika kritis menjauhkan khalayak dari realita, dapat memengaruhi cara berinteraksi dengan keluarga dan masyarakat sekitar, terjadinya pergeseran nilai-nilai agama dan moral pada khalayak, dapat merusak mental sekaligus pola pikir anak-anak mengingat peruntukan tayangan belum sepenuhnya tersegmentasi dengan benar berdasarkan tingkat kedewasaan usia.

Jika literasi Media sudah terbangun maka khalayak dapan melakukan langkah bijak untuk mengatasi dampak negatif terpaan tayangan televisi, yakni dengan selektif dalam memilih acara yang ditonton. Khalayak dapat memilih secara mandiri program-program acara yang dinilai memberikan manfaat bagi mereka. Selain itu mereka tidak menerima secara bulat-bulat tayangan yang menjauhkan mereka dari realitas sosial. Mereka juga dapat memberikan pendampingan kepada anak-anak, agar terpaan program yang belum pantas untuk disaksikan tidak sampai merusak konstruksi moral mereka. Perlu diingat bahwa tanyangan TV berpengaruh dalam pembentukan watak dan perilaku anak-anak lantaran media ini sekarang telah berfungsi sebagai rujukan atau wahana peniruan. Anak-anak sebagai salah satu konsumen media secara sadar atau tidak telah dicekoki budaya baru yang dikontruksi oleh pasar. 


\section{SIMPULAN}

Ibarat kawan sekaligus lawan, televisi memiliki peranan penting dalam kelangsungan peradaban hidup manusia. Tayangan televisi memberikan manfaat namun di sisi lain berdampak negatif bagi khalayaknya. Bijaksana dalam menghadapi terpaan tayangan televisi adalah cara paling efektif dalam meredam dampak negatif untuk saat ini, agar manfaat positif terasa lebih dominan memberikan kontribusi dalam pembangunan masyarakat Indonesia. Khalayak harus menyadari bahwa pada perkembangannya televisi swasta dewaa ini masih lebih berpihak pada industri dan pemilik modal, pemerintah pun hingga kini, belum sepenuhnya mampu melakukan pengawasan, pembinaan, dengan berbagai regulasi yang pernah dilahirkannya. Padahal televisi sebagai media massa audiovisual memiliki tingkat penetrasi tertinggi dibandingkan media-media. Tingkat penetrasi, artinya tingkatan dalam memengaruhi publik. Tingkatannya yang tinggi, artinya memiliki peranan penting: menjadi panduan khalayak.

Keberadaan Komisi Penyiaran Indonesia harusnya dapat menjadi otoritas independen yang mampu melakukan fungsi pengawasan termasuk penegakan regulasi terhadap konten tayangan televisi Indonesia. Namun KPI sendiri kesulitan untuk mengimplementasikan UU Penyiaran karena KPI tidak mempunyai kewenangan yang jelas, hanya sebatas memberikan teguran yang tidak serta merta dapat menghentikan siaran. Dengan peningkatan media literasi, khalayak dapat mandiri memberikan penawaran untuk mengatasi dominasi tayangan televisi yang berorientasi pada kepentingan ekonominya sebagai industri. Kritik dan selektivitas khalayak pada akhirnya yang dapat memaksa televisi kembali menjadi ruang publik ideal, yakni menjadi akses terhadap informasi pendidikan, kemanusiaan, agama dan lain-lain sehingga keberadaan televisi seiring sejalan dengan institusi pendidikan yang berorientasi pada dimensi kultural di ruang publik.

Literasi media televisi merupakan langkah strategis dalam memperbaiki isi siaran di televisi Indonesia. Dengan literasi, khalayak dapat mengkritisi isi siaran media penyiaran televisi dengan bijaksana. Dengan demikian secara otomatis perbaikan dan penyehatan isi siaran media penyiaran televisi akan berjalan dengan lebih baik dan efektif, sehingga dapat menciptakan martabat dan moral bangsa yang semakin baik. Semua ini berdasarkan pada fakta bahwa siaran televisi pada dasarnya merujuk pada selera pasar, artinya kendali pengaruh terpaan tayangan televisi berpulang pada khalayak itu sendiri.

\section{DAFTAR PUSTAKA}

Hamad, I. (2007). Membaca Televisi ala Al-Jabiri. Jurnal Komunikasi, vol.2 No.1, Oktober 2007.

Kriyantono, R. (2012). Teknik Praktis Riset Komunikasi. Jakarta: Kencana.

Livingstone, S. (2009). What is Media Literacy? LSE Research Online, diakses 19 februari 2013 dari http://eprints.lse.ac.uk

McQuail, D. (1987). Mass Communication Theory: An Introduction ( ${ }^{\text {nd }}$ eds). London: Sage.

Sanityastuti, M. S. (2007). "Membaca” Televisi Indonesia, Sebuah Upaya Menyikapi Tayangan Televisi, Jurnal Komunikasi, vol.2 No.1

Straubhaar \& LaRose. (2006). Media Now, Understanding Media, Culture and Technology. Belmont: Thomson Wadsworth. 
Suhandang, K. (2005). Periklanan; Manajemen, Kiat dan Strategi. Bandung: Nuansa.

Wardhana, V. Sp. (2001). Televisi dan Prasangka Budaya Massa. Jakarta: Media Lintas Inti Nusantara.

Widiyanto, P. (7 April 2011). Industri Televisi Mengarah Monopoli. Diakses pada 29 Agustus 2012 dari http://www.investor.co.id.

Wirodono, S. (2006). Matikan TV-mu: Terror Media Televisi di Indonesia. Yogyakarta: Resist Book.

Wirodono, S. (2011). Televisi Ruang Publik Yang Dirampok. Diakses 30 Agustus 2012 dari http://remotivi.or.id

Wolton, D. (2007). Kritik atas Teori Komunikasi: Kajian dari Media Konvensional Hingga Era Internet. Yogyakarta: Kreasi Kencana. 